Article

\title{
Implementing REDD+ in a Conflict-Affected Country: A Case Study of the Democratic Republic of Congo
}

\author{
H. Carolyn Peach Brown
}

University of Prince Edward Island, Charlottetown, PE C1A 3E5, Canada; hcpbrown@upei.ca; Tel.: +1-902-620-5066

Received: 3 August 2017; Accepted: 30 August 2017; Published: 5 September 2017

\begin{abstract}
Due to their carbon sequestration potential, tropical forests are a focal point for mitigation of climate change through Reducing Emissions from Deforestation and Forest Degradation (REDD+). The Democratic Republic of Congo (DRC) contains the largest part of the Congo Basin, the second largest rainforest in the world, and has become a main focus for REDD+ initiatives. However, DRC's ongoing instability and conflict threatens the peace and security of local people, and outcomes of such global initiatives. Content analysis of 102 documents from four major REDD+ initiatives intervening in DRC, sought to understand how civil conflict is being integrated into the discourse on REDD+ and its implication for climate change mitigation. Results showed that discussion of how conflict and political instability might impact REDD+ outcomes was limited. Concrete approaches to address the reality of civil conflict were not evident. Governance reform was, however, an important emphasis of REDD+ in DRC. Since REDD+, peace-building and development initiatives are often funded by the same institutions, it is important to begin a dialogue as to how they can be more intentional in harmonizing approaches in conflict-affected, forest-rich countries like DRC. Finding synergies has the potential to improve overall outcomes for the global climate, the forest, and the lives of local people.
\end{abstract}

Keywords: Africa; Congo Basin; REDD+; climate change; conflict

\section{Introduction}

Due to their high levels of biological diversity, protecting tropical forests has long been considered important by the international community. However, it is only just over a decade since their importance in relation to climate change has come to the fore. Storing more than double the amount of carbon in the atmosphere, forest ecosystems are an important component of the global carbon cycle [1]. As part of the terrestrial carbon sink, they absorb about $30 \%$ of the global carbon emissions from burning fossil fuels and net deforestation per year [1]. At a global scale, emissions related to deforestation are estimated to represent between 10 and $25 \%$ of global greenhouse gases [2-4].

Although the important role that forests play as a global terrestrial carbon sink was acknowledged in the United Nations Framework Convention on Climate Change (UNFCCC) Kyoto Protocol, it wasn't until the UNFCCC Conference of the Parties (COP) in 2005 that the importance of protecting tropical forests in addressing climate change became more prominent [5]. From this beginning, the recognition of the need to take action to reduce emissions from deforestation and forest degradation in developing countries, has evolved into a mechanism known as REDD+ (Reducing Emissions from Deforestation and Forest Degradation; and the role of conservation, sustainable management of forests and enhancement of forest carbon stocks in developing countries) [5]. With this approach, efforts are made to create a financial value for the carbon stored in forests through offering incentives for developing countries to better protect and sustainably manage their forests. In this way, the greenhouse gas (GHG) emissions produced from the removal and degradation of forests will be avoided and forest carbon stocks protected and enhanced [5,6]. Decisions about the implementation of REDD+ have been taken 
at a series of COPs with most of the REDD+ work program being finalized in 2013 and included in the 2015 Paris agreement [7,8]. In its decisions the UNFCCC recognized the need for international support for capacity-building and technical assistance, and coordination of results-based payments and finance in order to achieve results-based actions in developing countries [5].

International support for developing countries to implement REDD+ has come through a variety of initiatives. In 2008, building on the convening role and technical expertise of the Food and Agricultural Organization of the United Nations, the United Nations Development Programme, and the United Nations Environment Programme, the UN-REDD programme was developed [5]. The UN-REDD programme seeks to support developing countries' efforts to contribute to climate change mitigation through providing advisory and technical support according to their particular context [6]. A second key initiative under the UNFCCC is the Forest Carbon Partnership Facility (FCPF). Established and administered by the International Bank for Reconstruction, the FCPF is a partnership of developed and developing country governments, businesses, civil society, and indigenous peoples [9]. Through two funding mechanisms, the Readiness Fund and the Carbon Fund, the FCPF provides assistance to developing countries in implementing their efforts to reduce deforestation and forest degradation, conserve and enhance their forest carbon stocks, and sustainably manage their forests [10]. Other actors outside of the UNFCCC context are also implementing various approaches to REDD+ [5].

Forests in sub-Saharan Africa account for 10-20\% of global plant carbon [3]. The vast majority of that carbon, an estimated 25-60 billion metric tons, is found in the Congo Basin forest, the second largest contiguous tropical rainforest in the world [4,11-13]. Representing roughly 70\% of Africa's forests, it spans approximately 200 million hectares in the countries of Cameroon, Equatorial Guinea, Gabon, Central African Republic, the Republic of Congo, and the Democratic Republic of Congo (DRC) [4]. The DRC contains the largest percentage of the Congo Basin forest, accounting for approximately 23 billion tons of carbon, which represents one third of the total carbon pool of tropical Africa [11-13]. Deforestation rates in the Congo Basin have historically been low in comparison to the rest of the world, and also other African regions [3,4]. Deforestation rates are stable in some Congo Basin countries, but the rate has increased significantly in DRC. For these reasons, it is not surprising that the DRC has become a country of focus for REDD+ initiatives.

While the DRC has the potential to become one of the richest countries on the continent due to its vast forest and mineral resources, its population of 77 million people remain mired in poverty [14]. With a Gross National Income (GNI) per capita of 420 USD [15], the DRC ranks among the lowest countries in the world on the Human Development Index [16]. With a complex history of political violence, governance in the vast country is weak $[17,18]$. Also, the country has been recovering from a series of conflicts that occurred during the 1990s that has had an extremely negative effect on the population and economy, and which continues to influence ongoing instability in some areas [14]. A United Nations peace-keeping force has been on the ground in DRC for almost two decades [19]. While the last decade has been relatively stable, leading to political and economic reforms, this stability is threatened due to a delay in organization of elections and the President's determination to remain in power beyond constitutional limits [14,20]. The country also faces a humanitarian crisis with 3.8 million internally displaced persons, particularly in some regions, the most in Africa. It is also dealing with a steady flow of refugees from neighbouring countries; Burundi, Central African Republic, and South Sudan [21].

According to the Union of Concerned Scientists [22], the civil conflict in DRC has limited forest management reforms that have been successfully implemented in other parts of Central Africa [22]. Over the past decade, a number of international initiatives have been working in the DRC to build capacity and provide technical assistance to implement REDD+ [6,10,23,24]. The DRC national government has stated that REDD+ is at the centre of its national development and poverty reduction strategy [25,26]. Many of those involved in the process have expressed hope that the implementation of REDD+ could not only mitigate climate change, but also contribute to economic development, poverty reduction, biodiversity conservation, and governance reform [27]. However, some have questioned 
how REDD+ could be structured to lead to success in such fragile states [28-30]. According to Bertocchi and Guerzoni [31], the concept of state fragility is associated with various combinations of dysfunction including inability to provide basic services and meet vital needs, unstable and weak governance, a persistent condition of extreme poverty, lack of territorial control, and a high propensity to conflict and civil war. Such state fragility is considered to be predominantly caused by institutional factors [31]. Based on this definition, the DRC would be considered a fragile state.

Poor governance, sometimes connected to civil conflict, is seen as a major contributor to Africa's development problems [30,32]. Poor governance refers to deficits in accountability, transparency, citizen engagement, social inclusion, the rule of law, among others [32,33]. Therefore, it is not surprising that governance has been identified as one of the challenges for implementation of REDD+ in Africa [30]. According to Thompson et al [34], REDD+ is functioning as a form of governance, due to its specific framing of climate change and its legitimization of specific tools, actors, and approaches. Some have suggested that the success of REDD+ will depend on governance arrangements that bring together state and non-state actors in pursuing the common goal of mitigation of climate change [35]. Inherent to its success are the ways in which such arrangements are structured and the process for its implementation. However, REDD+ faces some governance challenges particularly related to the institutional arrangements for effective stakeholder participation and interest representation, organizational responsibility, its decision-making processes, and the implementation of decisions [36]. Standards for assessment of governance quality, including problem solving and resolution of conflict, are therefore important to understanding its success $[35,36]$.

In moving forward in fragile and conflict-affected countries, it is particularly important to understand the context and not ignore the reality of the impacts of civil conflict [37]. Using the DRC as a case study, this article explores the question of how REDD+ is being implemented in a country with a history of political instability and conflict. For this research, it uses a qualitative approach; a content analysis of publically available documents of four major international initiatives for REDD+ readiness, strategy design, and pilot projects in Africa [30]. The goal is not to evaluate the effectiveness of each of these individual initiatives, but to understand how conflict is being integrated into the discourse on REDD+ and its implications for the mitigation of climate change or often cited co-benefits, like poverty reduction and biodiversity conservation. Is there a discussion of how such civil conflict may negatively affect implementation of REDD+ policies and programs? If so, are measures suggested as to how it could be mitigated? Is REDD+ considered to be a way to address conflict and improve forest governance and if so, how is it being framed? Following a presentation of results, some implications for implementation of REDD+ initiatives in fragile states are discussed.

\section{Methods}

The 102 documents analysed for this research were from the following four major REDD+ initiatives (Table 1):

- UN-REDD programme [6]

- Forest Carbon Partnership Facility (FCPF) [10]

- Central African Forest Initiative (CAFI) [23]

- World Bank Forest Investment Program (FIP) [24]

These initiatives were chosen for analysis as they are the primary initiatives involved in implementing the REDD+ mechanism or in providing funds for the DRC to implement policies and projects related to the mechanism [30]. While the Congo Basin Forest Fund, set up in 2008, has also provided funding for REDD+ in the DRC, this initiative was not included in the analysis. In 2014, the major funders, Norway and Great Britain, announced that they would not be providing further funding, leading to the winding down of operations [38]. Both countries are now part of the Central African Forest Initiative. 
Table 1. General overview of approaches of the four initiatives.

\begin{tabular}{|c|c|c|}
\hline Initiative & General Approach & $\begin{array}{l}\text { Number of } \\
\text { Documents } \\
\text { Reviewed }\end{array}$ \\
\hline UN-REDD programme [6] & $\begin{array}{l}\text { Support nationally led REDD+ processes and promote the informed and meaningful involvement of all stakeholders, including } \\
\text { indigenous peoples and other forest-dependent communities, in the implementation of REDD+ activities. } \\
\text { Direct support to the design and implementation of National REDD+ Programmes and tailor support to national REDD+ actions. } \\
\text { Technical capacity building support through sharing of expertise, common approaches, analyses, methodologies, tools, data, } \\
\text { best practices and facilitating South-South knowledge sharing. }\end{array}$ & 46 \\
\hline $\begin{array}{l}\text { Forest Carbon Partnership } \\
\text { Facility (FCPF) [10] }\end{array}$ & $\begin{array}{l}\text { Readiness Fund and Carbon Fund provide financial and technical assistance to developing countries in implementing their } \\
\text { efforts related to REDD+; to reduce deforestation and forest degradation, conserve and enhance their forest carbon stocks, and } \\
\text { sustainably manage their forests. } \\
\text { Pilot a performance-based payment system for REDD+ activities, to ensure equitable benefit sharing and promote future } \\
\text { large-scale positive incentives for REDD+. } \\
\text { Within the approach to REDD+, test ways to sustain or enhance livelihoods of local communities and to conserve biodiversity. }\end{array}$ & 39 \\
\hline $\begin{array}{l}\text { Central African Forest } \\
\text { Initiative (CAFI) [23] }\end{array}$ & $\begin{array}{l}\text { Support strategic, holistic and country-level REDD+, and Low Emission Development investment. } \\
\text { Recognize and preserve the value of the forests to mitigating climate change, reducing poverty, and contributing to } \\
\text { sustainable development. } \\
\text { Develop and implement National Investment Frameworks (NIFs) endorsed at the highest level by national institutions with } \\
\text { cross-sectoral mandates. } \\
\text { Provide funding based on the achievement of policy and programmatic milestones that are spelled out in letters of intent. } \\
\text { Encourage donor coordination and alignment of bilateral assistance to partner countries based on NIFs. } \\
\text { Promote inclusive participation of all stakeholders. }\end{array}$ & 7 \\
\hline $\begin{array}{l}\text { World Bank Forest } \\
\text { Investment Program (FIP) } \\
{[24]}\end{array}$ & $\begin{array}{l}\text { Provide grants and low-interest loans to support developing countries in REDD+ implementation, with funding from the } \\
\text { Climate Investment Fund. } \\
\text { Direct investments designed to benefit the forest, development, and the climate are channeled through partner multilateral } \\
\text { development banks. } \\
\text { Contributes to other benefits such as biodiversity conservation, poverty reduction and protection of the rights of indigenous } \\
\text { peoples and local communities. }\end{array}$ & 10 \\
\hline
\end{tabular}


A search was conducted of the web sites of each of the previously named four initiatives for publically available documents, in English and French, related to their approach to implementation of REDD+ in general and the DRC, in particular. Web site searches took place over the period from 7 to 25 July 2017. Documents were downloaded from the sites and analysed using the NVivo 10 qualitative data analysis software. In order to gain an understanding of the more recent evolution of the REDD+ interventions in DRC, emphasis was placed on analysing documents from the last five years (since 2012). Key founding documents for some institutions were also included in the analysis as they provided descriptions of the initiatives. General information from the web pages of these institutions that described the initiatives and their interventions in DRC was also included in research. In the content analysis, the themes explored related to conflict, instability and governance.

\section{Results}

\subsection{Overview of Approaches}

As stipulated in the Cancun Agreements, countries must have four elements in place for REDD+ implementation and to access results-based payments and results-based finance [5]. These are a National Strategy or Action plan, a national Forest Reference Level, a robust and transparent National Forest Monitoring System, and a Safeguard Information System. National governments play a central role in designing and implementing these systems and programs, with the full engagement of all relevant stakeholders, including all those who benefit from forests or whose activities impact forests. This includes political and customary leaders at various levels of governance, as well as the private sector, civil society, and indigenous peoples. The activities associated with REDD+ take place in three phases, the Readiness phase, the Implementation phase, and the Results-based actions phase [5].

The UN-REDD programme and the FCPF are key in providing a harmonized approach to support for countries as they progress through these three phases (Table 1). Through providing knowledge and technical assistance, the UN-REDD programme works with and builds national capacity with the goal of reducing forest emissions and enhancing forest carbon stocks while contributing to sustainable development [39]. With finances from the Readiness fund, the FCPF provides grant funding and technical assistance as countries develop strategies and policies, and institutional capacity as they progress through the Readiness process of development of Readiness Planning Idea Notes and Readiness Preparation Plans. The Carbon fund builds on the progress made in readiness and provides financing for Emissions Reduction Programs, which are designed to pilot performance-based payments for emission reductions from REDD+ [10].

While at the end of 2016, most UN-REDD partner countries were in the REDD+ readiness phase, the DRC had progressed through both the planning and implementation stages of REDD+ preparedness $[5,6,40]$. The DRC's National UN-REDD Programme was recently officially launched which includes the completion of key studies and in-country consultation processes, testing of REDD+ pilot projects, and the training of personnel. With support from the FCPF, the DRC was the first country to have finalized its Readiness package and among the first to be selected for Carbon fund financing [40,41]. The Mai Ndombe Emissions-Reduction program was developed by the government as a first step in implementing the country's national REDD+ strategy, as a model for green development in the Congo Basin, and for REDD+ results-based payments on climate action. The program aims to implement the country's green development vision by providing alternatives to deforestation and rewarding performance to mitigate climate change, reduce poverty, sustainably manage natural resources, and conserve biodiversity [26,42].

The seven countries or organizations that are part of the Central African Forest Initiative (CAFI) seek to recognize and preserve the value of the forests to mitigating climate change, reducing poverty, and contributing to sustainable development in the Central African region (Table 1) [43]. Intended to be a forum of partnership and cross-country learning within the region, the initiative intends to finance one national investment framework per eligible country, based on the country's strong 
commitment to national reforms to address the drivers of deforestation and forest degradation. In 2016, the DRC was the first country in Central Africa to sign a letter of intent for funding from CAFI [44]. With this contribution to its REDD+ National Fund as well as financing from other international initiatives, the government intends to finance its REDD+ National Strategy Framework adopted in 2012 , that it states will put the preservation of forests at the centre of its country's economic and human development $[26,40,44]$.

The World Bank Forest Investment Program, with funding from the Climate Investment Fund, provides grants and low-interest loans to support developing countries in REDD+ implementation (Table 1). These direct investments designed to benefit the forest, development, and the climate are channelled through partner multilateral development banks [45]. In the DRC, money is channelled through the African Development Bank for projects in three sub-national programs, Kinshasa, Kisangani, and Kanaga/Mbuji-Mayi [26,46]. The proposed development objective of these projects is to empower indigenous peoples and local communities to benefit from and engage in REDD+ polices and projects [46].

\subsection{Conflict and Instability}

Several aspects related to instability and conflicts in the DRC were noted in the analyses of the four initiatives (Table 2). However, for the most part across the initiatives, there was little discussion of how on-going civil conflict or any increase in political instability would impact forests or REDD+, or how it could be addressed.

Table 2. Characterization of conflict across the four initiatives.

\begin{tabular}{ll}
\hline Conflict & Description \\
\hline Source of deforestation & $\begin{array}{l}\text { Civil conflict in 1990s and early 2000s is recognized as a historical } \\
\text { driver of deforestation. }\end{array}$ \\
\hline $\begin{array}{l}\text { Resulting from insecurity of } \\
\text { tenure system }\end{array}$ & $\begin{array}{l}\text { The land is the exclusive property of the state, but the existence of } \\
\text { customary and other land use regimes is a potential source of local } \\
\text { conflict among stakeholders. }\end{array}$ \\
\hline Across economic sectors & $\begin{array}{l}\text { Different sectors (forestry, agriculture, mining) impact the forest } \\
\text { differently, meaning that initiatives in one sector may affect forest } \\
\text { outcomes in another sector. }\end{array}$ \\
\hline Civil conflict & $\begin{array}{l}\text { Violence could result from the current uncertain political process and } \\
\text { could increase deforestation due to break down in effective } \\
\text { forest governance. }\end{array}$ \\
\hline
\end{tabular}

The main focus related to conflict emerging from the analyses concerned conflict at the local level due to insecurity of the tenure system. While the land is the exclusive property of the state in $\mathrm{DRC}$, the existence of customary and other land use regimes is a potential source of conflict. All four initiatives included an emphasis on mechanisms to ensure the inclusion of all stakeholders and their concerns in discussions on the reform of DRC's land law. REDD+ initiatives are considered to be an important part of this process as tenure security is recognized as an enabling condition for REDD+ [39]. Some initiatives include a specific conflict resolution, grievance, and appeals mechanism as one aspect of their safeguard measures [47].

Historical conflict was recognized as a driver of deforestation, particularly when that conflict led to the internal displacement of people. The concentration of people in internally displaced people camps, particularly in the eastern part of the country, has put pressure on the surrounding forest, leading to localized deforestation. All initiatives set the description of their proposed activities in the context of the history of conflict in the country. The DRC is often referred to as being in a post-conflict situation, particularly since 2003, and there is only occasional mention of the ongoing instability and conflict in some areas. It was noted that the relative political stability over the last decade had led 
to investment in the country resulting in increased deforestation and GHG emissions. However, there was recognition in some initiatives that in spite of a decade of relative stability, the state was still fragile. Concern was raised that with any increase in political instability or conflict the deforestation rate would be increased. Any mitigation or co-benefits from REDD+ would also then be reduced. One project cites political and governance risks that could affect the outcomes, and there is some discussion of how those risks are being mitigated in project design [48].

Other mentions of conflict relate to the differing uses of the forest by various sectors, including mining, forestry, and agriculture. Understanding the drivers of deforestation and forest degradation is considered to be an essential element for implementation of REDD+ [5]. Analysis of documents indicated consensus on direct drivers of deforestation including agriculture, logging, fuel wood, mining, and bushfires. Therefore, a multi-sectoral approach in REDD+ is seen as being vital to its success. Given the state's lack of capacity and history of weak governance, it is not surprising then that building capacity and governance reform are key emphases in these REDD+ initiatives. However, how governance reforms might be influenced by, or address on-going localized violence, or an increase in instability of the national government, was not specifically mentioned.

\subsection{REDD+ and Governance Reform}

As stated previously, one of the four elements for REDD+, under the UNFCCC, is a Safeguard Information System [5]. One of those safeguards is that REDD+ actions complement or are consistent with the objectives of the national forest program. Furthermore, transparent and effective national forest governance structures need to be put in place. This includes enforcement of the rule of law, coherence of national and subnational legal, policy and regulatory frameworks for transparent and effective forest governance, the institutional capacity for sustainable forest management, among others [5]. Consequently, governance is a cross-cutting theme for the UN-REDD programme [39].

According to the Worldwide Governance Indicators, the DRC ranks very low on all aspects of governance, including political stability and absence of violence, rule of law, government effectiveness, control of corruption, among others [33]. Therefore, given this reality in a country with a history of conflict and fragility, governance is an important focus in REDD+ initiatives in DRC. Poor governance is considered to be an underlying cause of deforestation in DRC and so all the initiatives seek to build technical and institutional capacity so that the government will be able to address the primary drivers. Corruption and lack of transparency are ongoing concerns and so an emphasis is placed on providing support to ensure good governance, improvement of public finance, and transparency in the management of REDD+ funds, public and natural resources. Modelling of outcomes of REDD+ in $\mathrm{DRC}$, indicated that while ambitious, if the country continues to improve its governance, promoting sustainable use of forest resources, forest-based livelihoods, and the national REDD+ programme, social, economic, and environmental benefits can be realized [49].

Since 2002, DRC has been reviewing its forest code, and REDD+ initiatives are assisting in that process, while also seeking to build inter-sectoral coordination. For example, one program funded by the FIP, seeks to combine activities to strengthen governance, build capacity, address local level land-use planning, secure land tenure, as well as sectoral activities, such as improved agricultural practices, reduced impact logging, fire management, and charcoal production. Given its technical and institutional complexities, the REDD+ requires substantial capacity at all levels, national, provincial, and community. Despite some progress, REDD+ is still very much focused on the capital of Kinshasa, with little capacity developed at the provincial or local levels, except where there are pilot projects.

\section{Discussion}

Given the history and continuing reality of instability and civil conflict in a fragile state, such as the DRC, it might have been expected that such issues would have been given greater treatment in documents related to the implementation of REDD+. While it is certainly acknowledged, for the 
most part it is given only passing reference with little discussion as to how it is currently affecting forests or the REDD+ initiatives on mitigation of climate change, or how it might do so in the future. There appears to be no discussion of concrete approaches to better integrate the reality of civil conflict into approaches to REDD+. It is possible, however, that such discussions about how ongoing instability and the possible escalation of violence will affect REDD+ initiatives and outcomes are taking place, but those in the public domain are silent on the subject.

As indicated in the results, the framing of conflict was often in relation to the local level and to issues of tenure security. This is not without merit. Karsenty and Assembé [50] state that it is essential in Central Africa that land tenure systems be reformed to respond to the tenure security aspirations of people, as well as international agendas on climate change. Many are hopeful that REDD+ has the potential to recognize or expand the rights of forest-based people, but fear that it will impose externally designed rules and fail to defend and secure community tenure rights, with negative consequences for people's livelihoods and the environment [51]. This fear is not without foundation, while cooperation is often common in early stages of REDD+ implementation, power struggles emerge when policy actors must decide on the concrete details of REDD+ strategies [52]. The outcomes of such power struggles will very much depend on the REDD+ structure and process of institutional arrangements in a particular country [36]. Unfortunately, studies of REDD+ governance quality have raised concerns about some of its challenges particularly related to the capacity and resources that would facilitate meaningful stakeholder participation [36,53]. Cadman et al. [36] suggest that it is imperative that international institutions address such concerns so that REDD+ can meet its environmental, economic, and social goals. While a certain level of conflict or disagreement may be necessary for progress in REDD+ decision-making [52], in a country like DRC which is already experiencing a lot of conflict, it is even more critical that attention be paid to its structure and process at all levels so as not to create other sources of conflict.

The cross-cutting emphasis on governance reform and institutional capacity building in REDD+ initiatives in the DRC is an attempt to counteract the dysfunctions of a fragile state. The focus on the central role of the national government in REDD+, in concert with a requirement to engage all relevant stakeholders, addresses some important indicators of good governance. Based on research in post-conflict Sierra Leone, it is suggested that being responsive to the needs of people is the key to successful trust building. National governments must demonstrate real concern for the needs of local people and engage them in policy making in order to enhance political trust [54]. Good governance, locally, as defined as a decrease in political corruption, and increased trust in politicians and political performance, is associated with a lower probability of conflict-related violence at the subnational level [55]. Therefore, REDD+ requirements to address issues of tenure security at the local level, a key aspect of governance reform, could mitigate potential conflict over forests at the local level. However, much existing conflict in DRC is not directly related to tenure security. The large numbers of internally displaced people often result from diverse drivers including inter-ethnic violence [18], yet there is no reference to how such conflict will affect REDD+ outcomes or how it could be addressed in initiatives. Nor is there discussion of the impacts of the large numbers for refugees.

Another question remains as to whether or not the mitigation agenda of REDD+ initiatives with their potential co-benefits can or should be more explicitly integrated into the peace-building agenda. In Liberia, international peace-builders placed forest governance reform high on the agenda leading to a reduced likelihood that timber revenues would reignite conflict [56]. This would indicate that the forest governance reform emphasis of REDD+ is well-placed, if not framed specifically as peace-building in the documents analysed. However, sometimes international interventions made peace-building more challenging in Sierra Leone and Liberia, so it would be important to avoid such problems with REDD+ initiatives [57]. A study in post-conflict reconstruction in eastern DRC, emphasized the importance of understanding and adjusting to local realities [32].

The DRC is highly vulnerable to climate change due to its poor governance and political violence, as well as low household and community resilience [32]. While it has been argued that more integration 
is required, typically peace-building programs and climate change programs in general have been separate [58]. Furthermore, climate change adaptation and mitigation interventions are often on separate tracks [59]. Yet, there are many opportunities to integrate climate change adaptation and mitigation into peace-building if coordination and other obstacles can be addressed [58].

REDD+, peace-building, and development initiatives are often funded by the same institutions, organizations, and countries. While climate-smart development is part of the of REDD+ agenda, explicit peace-building in conflict-affected countries appears not to be. However, given the current reality of a conflict-affected and forest-rich country like DRC, it is important for supporters to begin a dialogue as to how they can be more intentional in harmonizing their approaches. For example, international "food for peace" initiatives in the DRC respond not only to acute food security needs, but also fund longer-term development through various non-governmental organisation (NGO) projects related to improvement of agriculture, natural resource management, and biodiversity conservation, civil participation and local governance, among others [60]. Such initiatives have much in common with REDD+ initiatives. Finding other such synergies between REDD+ and peace-building has the potential to improve overall outcomes for the forest, the lives of local people, and the global climate.

\section{Conclusions}

The REDD+ mechanism approved under the UNFCCC process has become an important focus for climate change mitigation in developing countries. To reduce greenhouse gas emissions, efforts are made to create a financial value for the carbon stored in forests through offering incentives for countries to better protect and enhance their carbon stocks through sustainable management of their forests. Containing approximately $70 \%$ of the forests in Africa, the Congo Basin has become a focal point for REDD+. In particular, over the past decade a number of REDD+ international initiatives have been intervening in the DRC, a country which contains the largest percentage of the Congo Basin forest, and thereby roughly one third of the total carbon pool of tropical Africa. These initiatives are seeking to build capacity and provide technical assistance to implement REDD+.

DRC is a rich country in terms of resources but has a complex history of political violence and weak governance. The country has been recovering from a series of conflicts that occurred during the 1990s and which continue to influence ongoing instability. The country also faces a humanitarian crisis with the largest number of internally displaced persons in Africa and a steady flow of refugees from neighbouring countries. The DRC national government has stated that REDD+ is at the centre of its national development and poverty reduction strategy. Many of those involved in REDD+ in DRC have expressed hope that implementation of REDD+ could not only mitigate climate change, but also contribute to economic development, poverty reduction, biodiversity conservation, and governance reform.

Using the DRC as a case study, this research explored the question of how REDD+ is being implemented in a country with a history of political instability and conflict. Through a content analysis of publically available documents of four major international initiatives for REDD+ readiness, strategy design and pilot projects, it sought to understand how conflict is being integrated into the discourse on REDD+ and its implications for the mitigation of climate change or other co-benefits.

Results showed that discussion of conflict in the documents was often in relation to the local level and to issues of tenure security. A related aspect was a cross-cutting emphasis on governance reform and institutional capacity building in REDD+ initiatives to address issues of weak governance. However, discussion of how conflict and political instability is currently affecting forests or the REDD+ initiatives on mitigation of climate change, or how it might do so in the future was limited. Concrete approaches to better integrate the reality of civil conflict into approaches to REDD+ were not evident. Given the impact civil conflict can have on REDD+ outcomes, it is important that discussion of such issues be given a more prominent place in REDD+ initiatives. 
It has been suggested that there needs to be more integration of peace-building programs and climate change programs in conflict-affected countries like DRC. While climate-smart development is part of the of REDD+ agenda, explicit peace-building in conflict-affected countries is not. Since REDD+, peace-building and development initiatives are often funded by the same institutions, it is important to begin a dialogue as to how they can be more intentional in harmonizing approaches in conflict-affected, forest-rich countries like DRC. While not without its complexities, finding such synergies has the potential to improve overall outcomes for the global climate, the forest, and the lives of local people.

Acknowledgments: The author thanks two anonymous referees for their helpful comments on this article.

Conflicts of Interest: The author declares no conflict of interest.

\section{References}

1. Canadell, J.G.; Raupach, M.R. Managing forests for climate change mitigation. Science 2008, 320, $1456-1457$. [CrossRef] [PubMed]

2. Streck, C.; Robert, O.S.; Janson-Smith, T.; Tarasofsky, R. Climate Change and Forests: Emerging Policy and Market Opportunities; Royal Institute of International Affairs: London, UK, 2008; p. 346.

3. De Wasseige, C.; Tadoum, M.; Eba'a Atyi, R.; Doumenge, C. The Forests of the Congo Basin-Forests and Climate Change; Neufchâteau: Weyrich, Belgium, 2015; p. 128.

4. Megevand, C. Deforestation Trends in the Congo Basin; The World Bank: Washington, DC, USA, 2013; p. 179.

5. United Nations Development Program (UNDP). Towards a Common Understanding of REDD+ under the UNFCCC; Technical Resource Series 3; UN-REDD: New York, NY, USA, 2016; p. 128.

6. UN-REDD Programme. The United Nations Collaborative Programme on Reducing Emissions from Deforestation and Forest Degradation in Developing Countries. Available online: http:/ /www.un-redd.org/ (accessed on 12 July 2017).

7. United Nations Framework Convention on Climate Change (UNFCCC). Warsaw Framework for REDD-Plus. Available online: http://unfccc.int/land_use_and_climate_change/redd/items/8180.php (accessed on 7 July 2017).

8. United Nations Framework Convention on Climate Change (UNFCCC). The Paris Agreement. Available online: http:/ / unfccc.int/paris_agreement/items/9485.php (accessed on 14 July 2017).

9. International Bank for Reconstruction. Charter Establishing the Forest Carbon Partnership Facility; The World Bank Group: Washington, DC, USA, 2015; p. 62.

10. Forest Carbon Partnership Facility. Available online: https://www.forestcarbonpartnership.org/ (accessed on 12 July 2017).

11. Hoare, A.L. Clouds on the Horizon: The Congo Basin Forests and Climate Change; The Rainforest Foundation: London, UK, 2007; p. 26.

12. De Wasseige, C.; Devers, D.; de Marcken, P.; Eba'a Atyi, R.; Nasi, R.; Mayaux, P. Les Forêts du Bassin du Congo-Etat Des Forêts 2008; Office des publications de l'Union européenne: Luxembourg City, Luxembourg, 2009; p. 426.

13. Saatchi, S.; Xu, A.; Meyer, V.; Ferraz, A.; Yan, Y.; Shapiro, A.; Witteger, L.; Lee, M.; Tshibasu, E.; Banks, N. Carbon Map of DRC; University of California Los Angeles: Los Angeles, CA, USA, 2017; p. 64.

14. The World Bank. Democratic Republic of Congo Overview. Available online: http://www.worldbank.org/ en/country/drc/overview (accessed on 25 July 2017).

15. The World Bank. World Data Bank: World Development Indicators. Available online: http:/ / databank.worldbank.org/data/Views/Reports/ReportWidgetCustom.aspx?Report_Name= CountryProfile\&Id=b450fd57\&tbar=y\&dd=y\&inf=n\&zm=n\&country=COD (accessed on 25 July 2017).

16. United Nations Development Program. International Human Development Indicators. Available online: http:/ / hdr.undp.org/en/data/trends / (accessed on 25 July 2017).

17. Busby, J.W.; Smith, T.G.; White, K.L.; Strange, S.M. Locating Climate Insecurity: Where Are the Most Vulnerable Places in Africa? Robert S. Strauss Center for International Security and Law at the University of Texas: Austin, TX, USA, 2010; p. 60.

18. Mushi, F.M. Insecurity and local governance in Congo's South Kivu. IDS Bull. 2013, 44, 15-29. [CrossRef] 
19. United Nations. United Nations Organization Stabilization Mission in the Democratic Republic of Congo. Available online: http://www.un.org/en/peacekeeping/missions/monusco/background.shtml (accessed on 1 August 2017).

20. International Crises Group. Democratic Republic of Congo. Available online: http:/ /www.crisisgroup.org/ en/regions / africa/central-africa/dr-congo.aspx (accessed on 25 July 2017).

21. United Nations. United Nations Relief Chief Appeals for Urgent Funds for People in Need in the DR Congo. Available online: http:/ / reliefweb.int/report/democratic-republic-congo/united-nations-reliefchief-appeals-urgent-funds-people-need-dr (accessed on 25 July 2017).

22. Boucher, D.; Elias, P.; Faires, J.; Smith, S. Deforestation Success Stories: Tropical Nations Where Forest Protection and Reforestation Policies Have Worked; Union of Concerned Scientists Tropical Forest and Climate Initiative: Bogor, Indonesia, 2014; p. 64.

23. Central African Forest Initiative (CAFI). Central African Forest Initiative. Available online: http:/ / www.cafi. org/ (accessed on 13 July 2017).

24. The World Bank Forest Investment Program. Forest Investment Program. Available online: https://www. climateinvestmentfunds.org/fund/forest-investment-program (accessed on 13 July 2017).

25. Democratic Republic of Congo. Inventing REDD+; UN-REDD Programme, FAO, UNDP, UNEP, Forest Carbon Partnership Facility: Kinshasa, DRC, 2010; p. 21.

26. Forest Carbon Partnership Facility and UN-REDD programme. National REDD+ Framework Strategy of the Democratic Republic of Congo: Summary for Decision-Makers; FCPF and UN-REDD: Kinshasa, DRC, 2012; p. 23.

27. Brown, H.C.P.; Smit, B.; Sonwa, D.J.; Somorin, O.A.; Nkem, J.N. Institutional perceptions of opportunities and challenges of REDD+ in the Congo Basin. J. Environ. Dev. 2011, 20, 381-404. [CrossRef]

28. Karsenty, A.; Ongolo, S. Can "fragile states" decide to reduce their deforestation? The inappropriate use of the theory of incentives with respect to the REDD mechanism. For. Policy Econ. 2012, 18, 38-45. [CrossRef]

29. Aquino, A.; Guay, B. Implementing REDD+ in the Democratic Republic of Congo: An analysis of the emerging national REDD+ governance structure. For. Policy Econ. 2013, 36, 71-79. [CrossRef]

30. Gizachew, B.; Astrup, R.; Vedeld, P.; Zahabu, E.A.; Duguma, L.A. REDD+ in Africa: Contexts and challenges. Nat. Resour. Forum 2017, 41, 92-104. [CrossRef]

31. Bertocchi, G.; Guerzoni, A. Growth, history, or institutions: What explains state fragility in sub-Saharan Africa? J. Peace Res. 2012, 49, 769-783. [CrossRef]

32. Milabyo Kyamusugulwa, P.; Hilhorst, D.; Van der Haar, G. Capacity builders for governance: Community-driven reconstruction in the Eastern Democratic Republic of Congo. Dev. Pract. 2014, 24, 812-826. [CrossRef]

33. The World Bank Group. Worldwide Governance Indicators. Available online: http:/ / info.worldbank.org/ governance/wgi/\#reports (accessed on 1 August 2017).

34. Thompson, M.C.; Baruah, M.; Carr, E.R. Seeing REDD+ as a project of environmental governance. Environ. Sci. Policy 2011, 14, 100-110. [CrossRef]

35. Cadman, T.; Maraseni, T. The governance of climate change: Evaluating the governance quality and legitimacy of the United Nations REDD-plus programme. Int. J. Clim. Chang. Impacts Responses 2011, 2, 103-123.

36. Cadman, T.; Maraseni, T.; Ok Ma, H.; Lopez-Casero, F. Five years of REDD+ governance: The use of market mechanisms as a response to anthropogenic climate change. For. Policy Econ. 2017, 79, 8-16. [CrossRef]

37. Maxwell, D.; Mazurana, D.; Wagner, M.; Slater, R. Livelihoods, Conflict and Recovery: Findings from the Secure Livelihoods Research Consortium; Secure Livelihoods Research Consortium: London, UK, 2017; p. 46.

38. Climate Funds Update. Congo Basin Forest Fund. Available online: http:/ / www.climatefundsupdate.org/ listing/congo-basin-forest-fund (accessed on 1 August 2017).

39. UN-REDD Programme. UN-REDD Programme Strategic Framework 2016-2020; UN-REDD: Washington, DC, USA, 2015; p. 33.

40. Democratic Republic of Congo. REDD+ Investment Plan (2015-2020); Government of DRC: Kinshasa, DRC, 2015; p. 33.

41. Forest Carbon Partnership Facility. Forest Carbon Partnership Facility Information Card; FCPF: Washington, DC, USA, 2015. 
42. The World Bank. Forest and Climate-Smart Development in the Democratic Republic of Congo. Available online: http:/ / blogs.worldbank.org/climatechange/forest-and-climate-smart-development-democraticrepublic-congo (accessed on 2 August 2017).

43. Central African Forest Initiative (CAFI). Central African Forest Initiative-CAFI Joint Declaration; CAFI: Châtelaine, Switzerland, 2015; p. 2.

44. United Nations Development Program. Major Agreement between CAFI and the DRC Sets Best Practices to Prevent Tree Loss and Ensure Sustainable Development; UNDP: New York, NY, USA, 2016.

45. Climate Investment Funds. Forest Investment Program Fact Sheet; The World Bank: Washington, DC, USA, 2016; p. 4.

46. The World Bank. Project Information Document (PID) Concept Stage; The World Bank: Washington, DC, USA, 2014.

47. The World Bank. Climate Investment Funds: Investment Plan Democratic Republic of Congo; The World Bank: Washington, DC, USA, 2011; p. 146.

48. Forest Carbon Partnership Facility. Emissions Reduction Program Document; FCPF: Washington, DC, USA, 2016 ; p. 314.

49. UN-REDD Programme. Modelling REDD+ in the Democratic Republic of Congo; UNEP: Nairobi, Kenya, 2016; p. 8.

50. Karsenty, A.; Assembé, S. Land tenure and implementation of REDD+ in Central Africa. Land Tenure J. 2011, 2, 105-129.

51. Larson, A.M. Forest tenure reform in the age of climate change: Lessons for REDD+. Glob. Environ. Chang. 2011, 21, 540-549. [CrossRef]

52. Brockhaus, M.; Di Gregorio, M. National REDD+ policy networks: From cooperation to conflict. Ecol. Soc. 2014, 19, 14. [CrossRef]

53. Cadman, T.; Maraseni, T. More equal than others? A comparative analysis of state and non-state perceptions of interest representation and decision-making in REDD+ negotiations. Innov.: Eur. J. Soc. Sci. Res. 2013, 26, 214-230. [CrossRef]

54. Wong, P.-H. How can political trust be built after civil wars? Evidence from post-conflict Sierra Leone. J. Peace Res. 2016, 53, 772-785. [CrossRef]

55. Wig, T.; Tollefsen, A.F. Local institutional quality and conflict violence in Africa. Polit. Geogr. 2016, 53, 30-42. [CrossRef]

56. Beevers, M.D. Peace resources? Governing Liberia's forests in the aftermath of conflict. Int. Peacekeep. 2015, 22, 26-42. [CrossRef]

57. Beevers, M.D. Governing natural resources for peace: Lessons from Liberia and Sierra Leone. Glob. Gov. 2015, 21, 227-246.

58. Matthew, R. Integrating climate change into peace-building. Clim. Chang. 2014, 123, 83-93. [CrossRef]

59. Somorin, O.A.; Brown, H.C.P.; Visseren-Haamakers, I.; Sonwa, D.J.; Arts, B.; Nkem, J.N. The Congo Basin forest in a changing climate: Policy discourse on adaptation and mitigation. Glob. Environ. Chang. 2012, 22, 288-298. [CrossRef]

60. USAID. Food Assistance Fact Sheet-Democratic Republic of Congo; US Agency for International Development: Washington, DC, USA, 2017.

(C) 2017 by the author. Licensee MDPI, Basel, Switzerland. This article is an open access article distributed under the terms and conditions of the Creative Commons Attribution (CC BY) license (http:/ / creativecommons.org/licenses/by/4.0/). 